\title{
THE RHIZOSPHERE EFFECT IN TREES OF THE INDIAN CENTRAL HIMALAYA WITH SPECIAL REFERENCE TO ALTITUDE
}

\author{
ANITA PANDEY ${ }^{*}{ }^{1}$-LOK MAN S. PALNI ${ }^{2}$ \\ ${ }^{1}$ Environmental Physiology and Biotechnology, G. B. Pant Institute of Himalayan Environment \\ and Development, Kosi-Katarmal, Almora, 263 643, Uttaranchal, India \\ 2 (Present address): State Biotechnology Programme, Govt. of Uttaranchal, Biotech Bhavan, \\ P.O. Haldi (Pantnagar)- 263 146, U S Nagar. Uttaranchal, India \\ *Corresponding author: Anita Pandey: Environmental Physiology and Biotechnology, G. B. \\ Pant Institute of Himalayan Environment and Development, Kosi-Katarmal, Almora, 263 643, \\ Uttaranchal, India \\ e-mail: pandeyanita1@rediffmail.com \\ (Received $19^{\text {th }}$ Jan 2007 ; accepted $15^{\text {th }}$ Apr 2007)
}

\begin{abstract}
The present paper deals with the rhizosphere effect exerted on the microbial communities by ten representative and important tree species of the Indian Himalayan region. The study covered a wide altitudinal range (1200 to $3610 \mathrm{~m}$ above mean sea level) representing subtropical to subalpine climatic conditions. The rhizosphere to soil (R:S) ratio was found to range from 0.2 to $3.5,0.3$ to 2.9 , and 0.3 to 3.4, for bacteria, actinomycetes and fungi, respectively. Barring a few exceptions, generally the tree species of subtropical and temperate regions exerted a slight stimulatory effect on the rhizosphere microorganisms. Coniferous species of the subtropical and temperate locations viz., Cedrus, Pinus and Taxus supported relatively higher microbial population in the rhizosphere in comparison to other species. Abies pindrow (a conifer), Betula utilis, and Rhododendron campanulatum, species of the subalpine region were found to exert a distinct negative rhizosphere effect. The negative rhizosphere effect coincided with lowering of the soil $\mathrm{pH}$ in the rhizosphere region.
\end{abstract}

Keywords: rhizosphere, $R$ : S ratio, Himalayan trees, soil microbes, soil pH.

\section{Introduction}

Plant roots exert strong influence on the soil microbial populations; the term 'rhizosphere' was introduced by Hiltner in 1904 to denote the region of the soil that is subjected to the influence of plant roots [10]. In general the microbes that inhabit the rhizosphere serve as an intermediary between the plant, which requires soluble inorganic nutrients, and the soil, which contains the necessary nutrients but mostly in complex and inaccessible forms. Rhizosphere microorganisms thus provide a critical link between plant and soil environments. The magnitude of the rhizosphere effect depends mainly on the nature and amount of root exudates which appear to be related to plant age as well as species on one hand and edaphic and climatic factors on the other. The influence of individual plants is reflected in the rhizosphere as the R:S (rhizosphere to non rhizosphere ratio). For bacteria and fungi values commonly range from 5 to 20 . Actinomycetes, a somewhat less affected group of microorganisms by the rhizosphere, may reveal R:S ratios between 2 to 12 . Literature on various aspects of rhizosphere focusing on plant-microbe interactions or faunal-microbial interactions is extensive $[5,8,15,23,28,29,32,34]$.

The rhizosphere studies conducted so far, including those on rhizosphere effect and root exudation in particular, are largely based on short duration species $[9,26,31,33]$. 
Experiments have also been carried out under artificial conditions or simplified systems, such as hydroponic cultures with single plant species [1,23]. Only a limited number of reports exist on the rhizosphere effect in long duration plants or trees [6,7,11,14,18,24]. The present study was carried out to examine the rhizosphere effect in ten ecologically as well as economically important trees of the Kumaun region of Indian Central Himalaya, covering an altitudinal range from $1200 \mathrm{~m}$ to $3610 \mathrm{~m}$ amsl (above mean sea level), representing subtropical, temperate and subalpine zones.

\section{Materials and methods}

\section{Study site and collection of soil samples}

Samples, both from the rhizosphere and non-rhizosphere soils, were collected for all the plant species, from different altitudes in Kumaun Himalaya during the month of October. All the samplings were done in triplicates. Based on the altitude, the regions fall within the subtropical (1200 to $1800 \mathrm{~m}$ amsl); temperate (1800 to $2800 \mathrm{~m}$ amsl); and subalpine (2800 to $3800 \mathrm{~m}$ amsl) zones. The general account of tree species selected for the study, based on Osmaston (1978) [17], is summarized in Table 1. In case of rhizosphere sample, soil adhering to the plant roots was collected after removing the top litter layer $(5-10 \mathrm{~cm})$. The soil then was collected aseptically from the next 5-15 $\mathrm{cm}$ portion along the length of the root and placed in sterilized bags. For each sampling, the soil was taken at least from three points within the rhizosphere of the same plant and mixed. This represented one sample. Following this method, the soil samples were collected from three different plants (triplicates) for each species, from all the altitudes, separately. Non-rhizosphere soil sample (control), corresponding to each rhizosphere soil sample was collected, well away from roots of the respective plant species. In case of Betula utilis and Rhododendron campanulatum (3040 m amsl), the soil samples were collected from the mixed forest sites where the two species were growing in close proximity, with their roots intermingled. For all the species under study, soil samples were collected from 2 or 3 different altitudes.

\section{Enumeration of microorganisms}

Analyses of three groups of microorganisms, namely bacteria, actinomycetes and fungi were carried out on the basis of serial 10-fold dilutions- pour plate method, in duplicate, using triplicate samples (1g soil) and appropriate dilutions [12]; each value presented here is therefore an average of six individual counts. The method is known to provide valuable information while estimating comparative microbial populations [5]. All petridishes ( $90 \mathrm{~mm}$ dia; $25 \mathrm{ml}$ medium) were incubated at $21^{\circ} \mathrm{C}$ in the dark. Colony forming units (CFUs) were recorded ten days after incubation; the average number of CFUs per gram oven dry weight of soil was calculated as: $\mathrm{CFU}=$ Counts on the culture 
Table 1: General description of the ten plant species investigated in the present study * Name of the concerned district in the state of Uttaranchal, India is given in the parantheses

\begin{tabular}{|c|c|c|c|c|c|c|c|}
\hline Plant species & Family & $\begin{array}{l}\text { Local } \\
\text { name }\end{array}$ & $\begin{array}{l}\text { Angiosperm/ } \\
\text { Gymnosperm }\end{array}$ & $\begin{array}{l}\text { Deciduous/ } \\
\text { Evergreen }\end{array}$ & $\begin{array}{l}\text { Elevatio } \\
\mathrm{n}(\mathrm{m})\end{array}$ & Climate & Location* \\
\hline $\begin{array}{l}\text { Abies pindrow } \\
\text { Spach. }\end{array}$ & Pinaceae & Raga & Gymnosperm & Evergreen & $\begin{array}{l}2900 \\
3260 \\
3500\end{array}$ & $\begin{array}{l}\text { subalpine } \\
\text { subalpine } \\
\text { subalpine }\end{array}$ & $\begin{array}{l}\text { Himtoli } \\
\text { (Pithoragarh) } \\
\text { Nagling } \\
\text { (Pithoragarh) } \\
\text { Latakharak } \\
\text { (Chamoli) }\end{array}$ \\
\hline $\begin{array}{l}\text { Aesculus indica } \\
\text { Colebr ex Camb. }\end{array}$ & $\begin{array}{l}\text { Hippocastanac } \\
\text { eae }\end{array}$ & Pangar & Angiosperm & Deciduous & $\begin{array}{l}2200 \\
2260\end{array}$ & $\begin{array}{l}\text { temperate } \\
\text { temperate }\end{array}$ & $\begin{array}{l}\text { Khati } \\
\text { (Bageshwar) } \\
\text { Sela } \\
\text { (Pithoragarh) }\end{array}$ \\
\hline $\begin{array}{l}\text { Alnus nepalensis } \\
\text { Don }\end{array}$ & Betulaceae & Utees & Angiosperm & Deciduous & $\begin{array}{l}1200 \\
1880\end{array}$ & $\begin{array}{l}\text { subtropical } \\
\text { temperate }\end{array}$ & $\begin{array}{l}\text { Syalidhar } \\
\text { (Almora) } \\
\text { Tejam } \\
\text { Pithoragarh }\end{array}$ \\
\hline Betula utilis Don & Betulaceae & Bhojpatra & Angiosperm & Deciduous & $\begin{array}{l}3040 \\
3100 \\
3610\end{array}$ & $\begin{array}{l}\text { subalpine } \\
\text { subalpine } \\
\text { subalpine }\end{array}$ & $\begin{array}{l}\text { Golphur } \\
\text { (Pithoragah) } \\
\text { Dugtu } \\
\text { (Pithoragarh) } \\
\text { Phurkiya } \\
\text { (Bageshwar) }\end{array}$ \\
\hline $\begin{array}{l}\text { Cedrus deodara } \\
\text { (Roxb.) }\end{array}$ & Pinaceae & Deodar & Gymnosperm & Evergreen & $\begin{array}{l}1250 \\
1855\end{array}$ & $\begin{array}{l}\text { subtropical } \\
\text { temperate }\end{array}$ & $\begin{array}{l}\text { Hawalbag } \\
\text { (Almora) } \\
\text { Jageshwar } \\
\text { (Almora) }\end{array}$ \\
\hline $\begin{array}{l}\text { Pinus } \\
\text { rouxburghii } \\
\text { Sarg. }\end{array}$ & Pinaceae & Chir & Gymnosperm & Evergreen & $\begin{array}{l}1920 \\
2020\end{array}$ & $\begin{array}{l}\text { temperate } \\
\text { temperate }\end{array}$ & $\begin{array}{l}\text { Jageshwar } \\
\text { (Almora) } \\
\text { Jageshwar } \\
\text { (Almora) }\end{array}$ \\
\hline $\begin{array}{l}\text { P. wallichiana } \\
\text { Jackson }\end{array}$ & Pinaceae & Kail & Gymnosperm & Evergreen & 2800 & temperate & $\begin{array}{l}\text { Chaugla } \\
\text { (Pithoragarh) }\end{array}$ \\
\hline $\begin{array}{l}\text { Quercus } \\
\text { semecarpifolia } \\
\text { Sm. }\end{array}$ & Fagaceae & Kharsu & Angiosperm & Evergreen & $\begin{array}{l}1800 \\
2100\end{array}$ & $\begin{array}{l}\text { temperate } \\
\text { temperate }\end{array}$ & $\begin{array}{l}\text { Sela } \\
\text { (Pithoragarh) } \\
\text { Kilbari } \\
\text { (Nainital) }\end{array}$ \\
\hline $\begin{array}{l}\text { Rhododendron } \\
\text { campanulatum } \\
\text { Don }\end{array}$ & Ericaceae & Senru & Angiosperm & Evergreen & $\begin{array}{l}3040 \\
3190\end{array}$ & $\begin{array}{l}\text { subalpine } \\
\text { subalpine }\end{array}$ & $\begin{array}{l}\text { Golphur } \\
\text { (Pithoragarh) } \\
\text { Phurkiya } \\
\text { (Bageshwar) }\end{array}$ \\
\hline $\begin{array}{l}\text { Taxus baccata L. } \\
\text { sub sp. } \\
\text { wallichiana } \\
\text { (Zucc.) Pilger }\end{array}$ & Taxaceae & Thuner, & Gymnosperm & Evergreen & $\begin{array}{l}1855 \\
2400 \\
2960\end{array}$ & $\begin{array}{l}\text { temperate } \\
\text { temperate } \\
\text { subalpine }\end{array}$ & $\begin{array}{l}\text { Jageshwar } \\
\text { (Almora) } \\
\text { Eskmoru }\end{array}$ \\
\hline
\end{tabular}

plate $\mathrm{x}$ fresh weight of soil / oven dry weight of soil. A numerical value for the rhizosphere: soil (non-rhizosphere) ratio (R:S ratio) [13] of microbial counts was represented by letters (a-i) to represent $p$ values of $<0.001$ (a), $<0.005$ (b), $<0.010$ (c), $<0.025$ (d), $<0.050$ (e), $<0.100$ (f), $<0.200$ (g), $<0.400$ (h), and $<0.500$ (i).

The media (Hi Media, Bombay, India) used for microbial analyses were: (1) Nutrient agar for bacteria (5g tryptone, $2.5 \mathrm{~g}$ yeast extract, $1 \mathrm{~g}$ dextrose, $15 \mathrm{~g}$ agar; volume made up to 1 litre with distilled water), (2) Caseinate-asparagine agar for actinomycetes ( $2 \mathrm{~g}$ 
sodium caseinate, $0.1 \mathrm{~g}$ asparagine, $4 \mathrm{~g}$ sodium propionate, $0.5 \mathrm{~g}$ dipotassium phosphate, $0.1 \mathrm{~g}$ magnesium sulphate, $0.001 \mathrm{~g}$ ferrous sulphate, $15 \mathrm{~g}$ agar; volume made up to 1litre with distilled water), and (3) potato dextrose agar for fungi (potato infusion from $200 \mathrm{~g}$, $20 \mathrm{~g}$ dextrose, $15 \mathrm{~g}$ agar; with volume made up to 1 litre with distilled water).

\section{Preliminary observations on the microbial isolates}

The representative colonies of bacteria, actinomycetes and fungi were isolated and purified from the soil dilution plates by repeated subculturing until pure individual cultures were obtained. The isolates were identified up to the group or genus level using standard morphological, microscopic, cultural, and biochemical methods.

\section{Results}

The rhizosphere effect in the ten Himalayan trees examined in this study would seem to vary at the level of the species as well as the altitude. The rhizosphere of plants of the subtropical region was found to exert a stimulatory effect on the soil microbes. In case of Alnus nepalensis (1200 m elevation), stimulatory effect was observed on the microbial population, and the same was highly significant in case of bacteria $(\mathrm{P}<0.001)$. This could be clearly seen in terms of R:S ratio, the values being 3.5, 2.4 and 2.8 for bacteria, actinomycetes and fungi, respectively. The stimulatory effect would appear to decline with the elevation $(1880 \mathrm{~m})$; furthermore, an inhibitory effect was seen on the bacterial population $(\mathrm{P}<0.500)$. While a decline in the populations of actinomycetes and fungi, both for the rhizosphere and non-rhizosphere soils, was recorded, the R:S ratios were close to one (Fig. 1A, Table2). The microbial population of the rhizosphere soil of Quercus semecarpifolia and Aesculus indica, representatives of the temperate zone, was quite high. While in case of $Q$. semecarpifolia, the microbial population as well as R:S ratio registered a decline with increasing elevation, a positive rhizosphere effect was, however, seen at both the elevations (Fig. 1B, Table 2). The two sampling sites of Aesculus indica were fairly close $(2200$ and $2260 \mathrm{~m})$ and, the R:S ratio was found to range from 1.2 (fungi) to 2.5 (bacteria) (Fig. 1C; Table 2).

The microbial population of rhizosphere and bulk soil and the R:S ratio of five coniferous species studied, viz. Cedrus deodara, Pinus roxburghii, P. wallichiana, Taxus baccata, and Abies pindrow are presented in Figures $1 D-G$, and Table 2. The bacterial population in the rhizosphere soil of Cedrus deodara was significantly higher than that of the corresponding non-rhizosphere soil $(\mathrm{P}<0.001)$ at $1250 \mathrm{~m}$. The rhizospheric stimulation declined for bacteria and actinomycetes at $1855 \mathrm{~m}$ elevation.

However, the R:S ratio of fungi increased from 2.2 to 3.4. In case of both Pinus Table 2: R:S ratios of three groups of microorganisms and soil $\mathrm{pH}$ in respect of selected ten plant species species, a suppressive effect was seen in some instances. $P$. wallichiana exerted 
Table 2: $R$ :S ratios of three groups of microorganisms and soil $\mathrm{pH}$ in respect of selected ten plant species

\begin{tabular}{|c|c|c|c|c|c|c|}
\hline \multirow[t]{2}{*}{ Plant species } & \multirow{2}{*}{$\begin{array}{l}\text { Elevation } \\
\text { (m) amsl }\end{array}$} & \multicolumn{2}{|c|}{ Soil pH } & \multicolumn{3}{|c|}{ R:S ratio } \\
\hline & & Rhizosphere & $\begin{array}{c}\text { Non } \\
\text { rhizosphere }\end{array}$ & Bacteria & Actinomycetes & Fungi \\
\hline \multirow[t]{3}{*}{ Abies pindrow } & 2900 & 5.7 & $6.3(-0.6)$ & 0.7 & 0.7 & 1.1 \\
\hline & 3260 & 4.8 & $5.5(-0.7)$ & 0.4 & 0.4 & 1.3 \\
\hline & 3500 & 4.7 & $5.6(-0.9)$ & 0.3 & 0.4 & 0.8 \\
\hline \multirow[t]{2}{*}{ Aesculus indica } & 2200 & 6.5 & $6.6(-0.1)$ & 2.5 & 2.4 & 2.0 \\
\hline & 2260 & 6.3 & $6.5(-0.2)$ & 1.9 & 2.3 & 1.2 \\
\hline \multirow[t]{2}{*}{ Alnus nepalensis } & 1200 & 6.4 & $6.4(-0.0)$ & 3.5 & 2.4 & 2.8 \\
\hline & 1880 & 6.1 & $6.3(-0.2)$ & 0.8 & 1.2 & 1.1 \\
\hline \multirow[t]{2}{*}{ Betula utilis } & 3100 & 4.6 & $5.5(-0.9)$ & 0.3 & 0.5 & 0.8 \\
\hline & 3610 & 4.7 & $5.3(-0.6)$ & 0.4 & 0.5 & 0.9 \\
\hline $\begin{array}{l}\text { B. } \\
\text { utilis }+ \text { Rhododendron } \\
\text { campanulatum* }\end{array}$ & 3040 & 4.6 & $5.4(-0.8)$ & 0.2 & 0.3 & 0.3 \\
\hline \multirow[t]{2}{*}{ Cedrus deodara } & 1250 & 6.6 & $6.7(-0.1)$ & 2.6 & 2.3 & 2.2 \\
\hline & 1855 & 5.9 & $6.1(-0.2)$ & 1.3 & 1.5 & 3.4 \\
\hline \multirow[t]{2}{*}{ Pinus rouxburghii } & 1920 & 5.6 & $5.9(-0.3)$ & 1.1 & 0.9 & 2.8 \\
\hline & 2020 & 6.1 & $6.3(-0.2)$ & 1.1 & 1.2 & 1.3 \\
\hline P. wallichiana & 2800 & 5.4 & $5.5(-0.1)$ & 0.7 & 0.9 & 2.1 \\
\hline \multirow{2}{*}{$\begin{array}{l}\text { Quercus } \\
\text { semecarpifolia }\end{array}$} & 1800 & 6.6 & $6.3(+0.3)$ & 1.9 & 2.2 & 3.1 \\
\hline & 2100 & 6.3 & $6.1(+0.2)$ & 1.3 & 1.9 & 1.9 \\
\hline $\begin{array}{l}\text { Rhododendron } \\
\text { campanulatum }\end{array}$ & 3190 & 5.6 & $6.5(-0.9)$ & 0.4 & 0.3 & 0.7 \\
\hline \multirow[t]{3}{*}{ Taxus baccata } & 1855 & 6.3 & $6.4(-0.1)$ & 3.3 & 2.9 & 3.1 \\
\hline & 2400 & 6.3 & $6.4(-0.1)$ & 2.2 & 2.1 & 2.5 \\
\hline & 2960 & 5.4 & $5.3(+0.1)$ & 1.9 & 1.6 & 2.0 \\
\hline
\end{tabular}

$R=$ rhizosphere soil; $S=$ non-rhizosphere soil; values within parentheses indicate difference in the $\mathrm{pH}$ of rhizosphere soil over non-rhizosphere soil; amsl = above mean sea level

* At this site the roots of these two species were found to be highly intermingled.

inhibitory influence on the bacterial and actinomycetes populations at $2800 \mathrm{~m}$ elevation (Fig. 1E; Table 2). However, microbial population of the rhizosphere of Taxus baccata was stimulated at all three elevations, and the R:S ratios declined by increasing altitude (Fig. 1F; Table 2). 
Distinct suppressive effect on the rhizospheric microbial population was seen in Abies pindrow, a conifer of the subalpine region; it was particularly pronounced in case of bacteria and actinomycetes as shown by R:S ratios. The suppressive effect increased with elevation; the ratios recorded were: $0.7,0.4$, and 0.3 for bacteria and $0.7,0.4$ and 0.4 for actinomycetes, at 2900, 3260 and 3500 m elevation, respectively (Fig. 1G; Table 2).

(H) Betula utilis+Rhododendron campanulatum

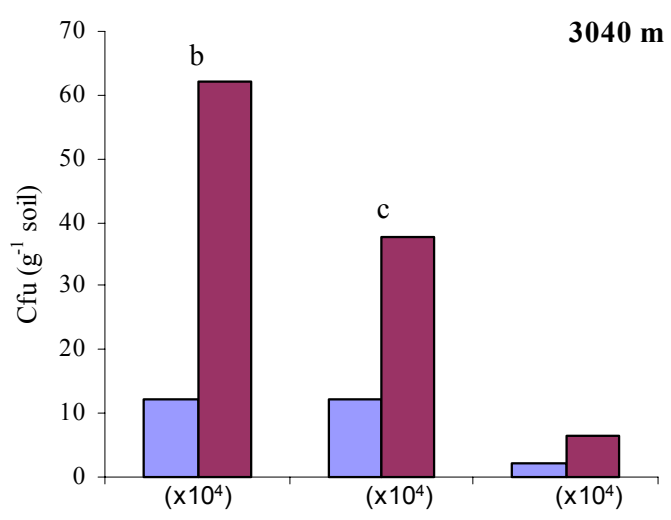

R. campanulatum

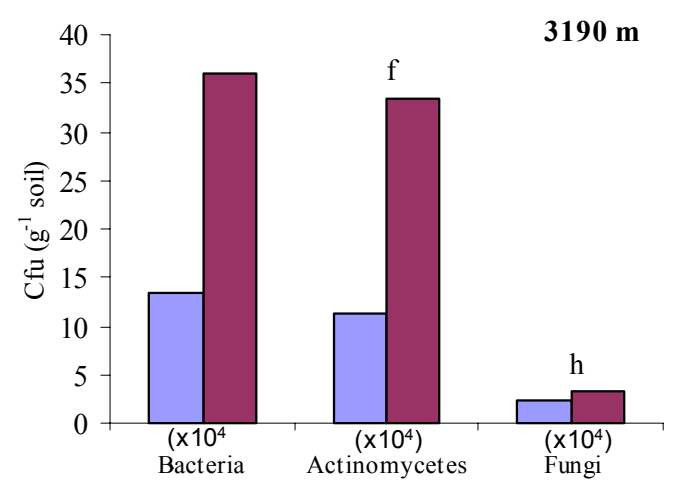

B. utilis

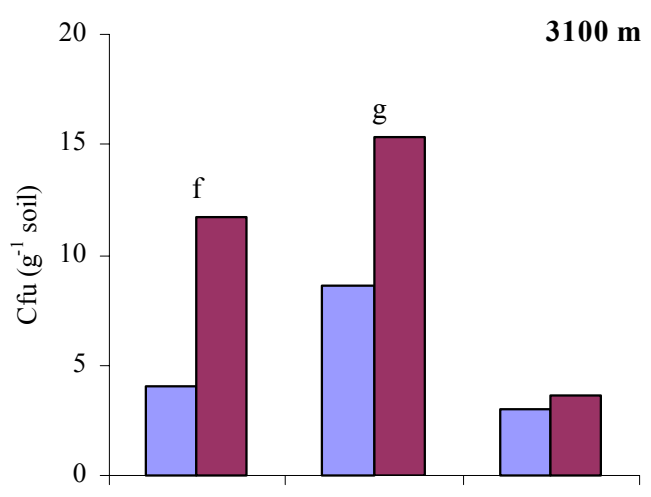

B. utilis

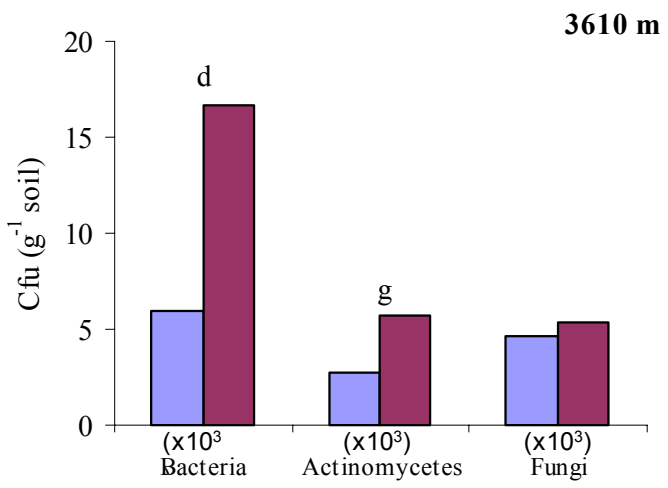

Figure 1. (A-H). Microbial populations of three groups of microorganisms in the rhizosphere and the corresponding non-rhizosphere soil samples of various trees. Letters a-i represent $p$ values of $<0.001(a),<0.005(b),<0.010(c),<0.025(d),<0.050(e),<0.100(f),<0.200(g)$, $<0.400(h)$, and $<0.500$ (i).

Betula utilis and Rhododendron campanulatum (both subalpine plants) also exerted a suppressive effect on the microbial communities in the rhizosphere. Significant inhibition of bacteria and actinomycetes was found in Betula utilis; R:S ratios did not change much with change in the altitude. A similar trend was observed also in the case of Rhododendron campanulatum. Even lower R:S ratios were obtained from regions where the roots of Betula utilis and Rhododendron campanulatum were found to be entangled (Fig. 1H; Table 2). 
Lowering in the $\mathrm{pH}$ of rhizosphere soil over the corresponding non-rhizosphere soil samples (0.6 to 0.9 units) was recorded in case of Abies pindrow, Betula utilis and Rhododendron campanulatum (Table 2).

On the basis of preliminary identification of representative colonies from the rhizosphere as well as non-rhizosphere soil samples in this study, the bacterial population was found to largely comprise species of Bacillus, Flavobacterium, Micrococcus, Pseudomonas, Rhodococcus, Serratia, Xanthomonas, and some other pigmented bacteria (data not presented). Similarly the fungal population was mainly represented by species of Aspergillus, Cladosporium, Fusarium, Penicillium, Paecilomyces, and Trichoderma. Actinomycetes were mainly dominated by species of Streptomyces.

\section{Discussion}

The classical concept of rhizosphere effect is based on the stimulation of microbial populations, at times fairly intense, in the region adjacent to the roots, as against the bulk soil. This has been based on the results of research conducted largely on short duration plants and only a few tree species. Rhizosphere : soil ratios between 100 and 400 have been reported for genge (Astragalus sinicus L.;), a legume where R:S ratios of 24.3, 5.5, 5.9, 3.3, 3.6, and 5.9 for bacteria have been reported for red clover, flax, oats, maize, barley, and wheat, respectively [27]. Ivarson and Katznelson (1960) reported R:S ratios between 8-10 for yellow birch [11]. In this study observations on the rhizosphere effect of ten trees of the Himalayan region have been described. The serial dilution plate count technique has been used throughout this investigation to maintain methodological consistency. The important findings of the present study are: (1) in general, the microbial population and the corresponding R:S ratio in long duration plants, e.g., perennial trees as in this case, are considerably lower in comparison to short duration species, e.g., annual crops, (2) the microbial population and the rhizosphere effect would appear to decrease by increasing the altitude, and (3) under cold and harsh climatic conditions of the subalpines, the tree root exudates tend to become more acidic, and exert a negative influence on the microbial population. It was considered that the rhizoflora of long lived plant species experiencing hard climatic conditions, such as low temperatures, heavy rainfalls and snow falls (e.g., temperate and subalpine climates), might go through various successions due to various biotic and abiotic pressures, resulting in dominance of selected microbial communities or populations. Occurrence of negative rhizosphere effect exerted by the established tea bushes in contrast to the normal stimulatory effect exhibited by the young tea bushes and development of a specialized microflora has been reported [18]. These studies were conducted on tea rhizosphere of young to established ( 4 to 123 years old) tea bushes, growing in temperate locations representing monsoonal and occasionally experiencing snow falls, of the Indian Himalayan region [21].

The influence of a particular plant species on the rhizospheric microbial population is conveniently illustrated by comparing the values for R:S ratio, which was found to range from 0.2 to 3.5 for bacteria, 0.3 to 2.9 for actinomycetes, and 0.3 to 3.4 in case of fungi, based on a total of ten tree species. Barring a few exceptions, the trees of sub tropical and temperate regions exerted a slight stimulatory effect on the rhizospheric microorganisms. Conifers of the sub tropical and temperate locations, namely Cedrus, Pinus and Taxus supported relatively higher microbial population in the rhizosphere in 
comparison to non-coniferous species. Abies pindrow (a conifer of subalpine region) exerted a distinct negative rhizosphere effect. Similarly two other species of the subalpine region, Betula and Rhododendron, also exerted suppressive effect on the rhizospheric communities.

The microbial population would appear to decrease with a concomitant increase in the altitude. This is clearly indicated by the values recorded for the population density, in a decreasing order, from $10^{6}$ (subtropical regions) to $10^{3}$ cells $\mathrm{g}^{-1}$ soil (alpine regions). The trend was similar for bacteria and actinomycetes, and the values were a little lower, i.e., $10^{5}$ to $10^{3}$ cells $\mathrm{g}^{-1}$ in case of fungi. Likewise the rhizosphere effect was also found to be influenced by change in the altitude. The values for $\mathrm{R}: \mathrm{S}$ ratio in many of the studied plants were found to decrease from sub tropical to temperate location, and in fact negative values were recorded in most samples of the subalpine region. In a recent study from Sikkim Himalaya (1200 m to $1900 \mathrm{~m}$ amsl) microbial population was also reported to decrease with increasing altitude [20].

The rhizosphere effect is affected by many factors, like the quantity and quality of root exudates secreted by a particular plant species, in addition to prevailing edaphic and climatic conditions. The effect of root exudates on the soil microflora of the rhizosphere is likely to be more intense, stimulatory or inhibitory, in case of trees, as influenced by the age of the tree. In fact, a tree rhizosphere is likely to develop a microenvironment continuously under the effect of the root exudates, soil characteristics and climatic factors, giving an opportunity for development of a specialized rhizoflora. The inhibitory effect on microbial populations reported in respect of established tea bushes was found to be correlated with the nature of root exudates, greater antagonistic activity, and lowering of the soil $\mathrm{pH}$ in the rhizosphere $[19,22]$. In the present study, interestingly, wherever an inhibitory effect on the rhizosphere microbes was observed, a concomitant decrease in the $\mathrm{pH}$ of rhizosphere soil was also recorded. This was particularly prominent in case of Abies pindrow, Betula utilis and Rhododendron campanulatum, important members of the subalpine vegetation. The root exudates in such cases may contain metabolites that might have suppressive effect on the rhizospheric microbial population.

Soil-chemical changes related to the release of organic and inorganic compounds, and the respective products of their microbial metabolism are important factors affecting microbial populations, availability of nutrients, solubility of toxic elements in the rhizosphere, and thereby the ability of plants to cope with adverse soil-chemical conditions. Organic compounds in root exudates are continuously metabolised by rootassociated microorganisms and in the rhizosphere. Quantitative and qualitative alterations of the root exudates composition occur due to the degradation of exudate compounds and the release of microbial metabolites. Mobilization of micronutrients or heavy metals in the rhizosphere has been also related to rhizosphere acidification and to complexities with organic acids in root exudates [16,23,32].

Although the focus of the present study was on the rhizosphere effect caused by ten Himalayan tree species on three important free living groups of microorganisms (bacteria, fungi, and actinomycetes) with special reference to the altitude, observations on other related biotic as well as abiotic aspects were also given due importance and are being studied separately. For example, in view of the importance of selection pressures causing the morphological divergence of roots with different types of mycorrhizas [2], detailed studies are being conducted on the mycorrhizal status of these species $[3,4]$. Similarly amongst the abiotic factors, soil $\mathrm{pH}$ as a single factor has been given 
importance affecting the soil microflora. Observations on other parameters of the soil samples have also been worked out in a separate study. While dominance of sand particles and almost similar moisture content was recorded in all the soil samples, a declining trend in the organic carbon content and no definite trend in nitrogen content were recorded. It was concluded that the soil characteristics were more influenced by the composition of the forest than to the elevation [25].

During the present study, a large number of bacteria, actinomycetes and fungi have been isolated from both the rhizosphere as well as non-rhizosphere soils; further investigations are in progress to understand the microbial diversity of colder regions, including the rhizospheric communities. These long term studies, and characterization of selected microbes will help in screening potentially beneficial microbes, especially the psychrotrophs, for biotechnological applications.

Acknowledgements. RS Rawal, SS Samant, LK Rai, D. Bisht, H Joshi, B. Kumar and P. Trivedi are thanked for help in the collection of soil samples and useful discussions. The Union Ministry of Environment and Forests, Department of Biotechnology, and the Council of Scientific and Industrial Research, New Delhi provided the financial support.

\section{REFERENCES}

[1] Baath, E., Olsson, S. \& Tunlid, A. (1988): Growth of bacteria in the rhizoplane and the rhizosphere of rape seedlings. -FEMS Microbiology Ecology 53: 355-360.

[2] Brundrett, M.C. (2002): Coevolution of roots and mycorrhizas of land plants.- New Phytologist 154: 275-304.

[3] Chaurasia, B., Pandey, A. \& Palni, L.M.S. (2005a): Occurrence of Arbuscular Mycorrhizae in the rhizosphere of Himalayan Yew (Taxus baccata L. subsp. wallichiana (Zucc.) Pilger)-A Case Study. In: Podila, G.K.\& Varma, A.K. (eds.): Basic Research and applications of Mycorrhizae. IK International Pvt. Ltd., New Delhi, pp. 26-35.

[4] Chaurasia, B., Pandey, A. \& Palni, L.M.S. (2005b): Distribution, Colonization and Diversity of Arbuscular Mycorrhizal fungi in Rhododendrons of central Himalayan region of India.- Forest Ecology \& Management. 207: 315-324.

[5] Curl, E.A. \& Truelove, B. (1986): The Rhizosphere. Springer Verlag, Berlin Heidel-berg New York.

[6] Dangerfield, J.A., Westlake, D.W.S. \& Cook, F.D. (1975): Quantitative assessment of the bacterial rhizosphere flora of Pinus contorta var. latifolia.- Canadian Journal of Microbiology 21: 2034-2038.

[7] Fogel, R. (1988): Interactions among soil biota in coniferous ecosystems. In: Edwards, C.A., Stinner, B.R.\& Rabatin, S. (eds): Biological interactions in soil.- Agriculture, Ecosystems \& Environment, 24: 69-85.

[8] Foster, R.C. (1986): The ultrastructure of the rhizoplane and rhizosphere.- Annual Review of Phytopathology 24: 211-34.

[9] Hale, M.G. \& Moore, L.D. (1979): Factors affecting root exudation II: 1970-1979.Advances in Agronomy 31: 93-124.

[10] Hiltner, L. (1904): Uber neuere Erfahrungen und Probleme auf dem Gebiet der Bodenbakteriologie und unter besonderer Berucksichtigung der Grundungung und Brache. [German].- Arb Dtsch Landwirtsch Ges. 98: 59-78.

[11] Ivarson, K.C. \& Katznelson, H. (1960): Studies on the rhizosphere microflora of yellow birch seedlings.- Plant \& Soil 12: 30-40.

[12] Johnson, L.F. \& Curl, E.A. (1972): Methods for research on the ecology of soil-borne plant pathogens. Bergess, Minneapolis. 
[13] Katznelson, H. (1946): The rhizosphere effect of mangels on certain groups of microorganisms.- Soil Science 62: 343-354.

[14] Lowe, W.E.\& Gray, T.R.G. (1973): Ecological studies on coccoid bacteria in a pine forest soil-III. Competitive interactions between bacterial strains in soil.- Soil Biology \& Biochemistry 5: 463-472.

[15] Lynch, J.M. (1990): The Rhizosphere. Academic Press, London.

[16] Marschner, H. (1995): Mineral nutrition of higher plants. Academic Press, London.

[17] Osmaston, A.E. (1978): A forest flora for Kumaun. International Book Distributors, Dehradun.

[18] Pandey, A.\& Palni, L.M.S. (1996): The rhizosphere effect of tea on soil microbes in a Himalayan monsoonal location.- Biology \& Fertility of Soils 21: 131-137.

[19] Pandey, A. \& Palni, L.M.S. (1997): Bacillus species: The dominant bacteria of the rhizosphere of established tea bushes.- Microbiological Research 152: 359-365.

[20] Pandey, A. \& Palni, L.M.S. (1998): Microbes in Himalayan soils: Biodiversity and potential applications.- Journal of. Scientific \& Industrial Research 57: 668-673.

[21] Pandey, A. \& Palni, L.M.S. 2004. Tea Rhizosphere: microbial Diversity and Characteristic features and comments on microbial communication in rhizosphere.- International Journal of Tea Science 3: (3\&4), 285-290.

[22] Pandey, A., Palni, L.M.S. \& Coulomb, N. (1997): Antifungal activity of bacteria isolated from the rhizosphere of established tea bushes.- Microbiology Research 152 (1): 105-112.

[23] Pinton, R., Varanini, Z. \& Nannipieri, P. (2001): The Rhizosphere. Marcel Dekker, Inc. New York, Basel.

[24] Rangaswami, G. \& Vasantharajan, V.N. (1962) Studies on the rhizosphere microflora of citrus tree. 1. Quantitative incidence of microorganisms in relation to root and shoot growth.- Canadian Journal of Microbiology 8: 473-477.

[25] Rawal, R.,S. \& Rai, L.K. (1998): Assessment of forest, soil and human patterns in Darma valley-Analysis of changes. Panchachuli Multidimensional Expedition, Corps of Engineers, Technical Report, GB Pant Institute of Himalayan Environment and Development, Kosi-Katarmal, Almora, India.

[26] Routt, J.W. \& Katznelson, H. (1961): A study of the rhizosphere soil of crop plants.Journal of Applied Bacteriology 24: 164-171.

[27] Rovira, A.D. (1965): Interactions between plant roots and soil microorganisms- Annual Review of Microbiology. 19: 241-266.

[28] Rovira, A.D. (1991): Rhizosphere research - 85 years of progress and frustration. In: Keister, D.L. \& Cregan, P.B. (eds): The rhizosphere and plant growth. Kluwer Academic Publishers, Netherlands, pp. 3-13.

[29] Russell, R.S. (1973): Soil conditions and plant growth. $10^{\text {th }}$ edn. Longmans, London.

[30] Snedecor, G.W. \& Cochran, W.G. (1967): Statistical methods. Oxford and IBH Publishing Co, New Delhi.

[31] Starkey, R.L. (1958): Inter-relations between microorganisms and plant roots in the rhizosphere.- Bacteriology Reviews 22: 154-172.

[32] Waisel, Y., Eshel, A. \& Kafkafi, U. (eds), (1991): Plant Roots- The Hidden Half. Marcel Dekkar, Inc. New York, Basel, Hong Kong.

[33] Walker, S.T., Bais, H.P., Grotewold, E. \& Vivanco, M. (2003): Root Exudation and Rhizosphere Biology ${ }^{1}$. Plant Physiology 132: 44-51.

[34] Whipps, J.M. (2001): Microbial interactions and biocontrol in the rhizosphere.- Journal of Experimental Botany 52 